\title{
Correction to: Large proportion of wood dependent lichens in boreal pine forest are confined to old hard wood
}

\author{
Francesca Santaniello ${ }^{1,2}$ (D) . Line B. Djupström ${ }^{1} \cdot$ Thomas Ranius $^{2} \cdot$ Jan Weslien $^{1}$. \\ Jörgen Rudolphi ${ }^{3}$. Göran Thor ${ }^{2}$
}

Published online: 4 September 2018

(c) Springer Nature B.V. 2018

\section{Correction to: Biodivers Conserv (2017) 26:1295-1310 https://doi.org/10.1007/s10531-017-1301-4}

In the original publication of the article, in Table 2 under the column "Observed frequency fire scars", the values of species Mycocalicium subtile were published incorrectly as "1" and " 0 ". However, the values should be " 0 " and " 1 ".

The original article can be found online at https://doi.org/10.1007/s10531-017-1301-4.

\section{Francesca Santaniello}

Francesca.Santaniello@skogforsk.se

1 The Forestry Research Institute of Sweden (Skogforsk), 75183 Uppsala, Sweden

2 Department of Ecology, Swedish University of Agricultural Sciences, Box 7044, 75007 Uppsala, Sweden

3 Department of Wildlife, Fish, and Environmental Studies, Swedish University of Agricultural Sciences, 90183 Umeå, Sweden 